Vol. 13, Issue 1, February: 2019

DOI: http://doi.org/10.4038/besl.v13i1.7665

\title{
Use of Façadism in Divided-Walled Nicosia, Cyprus
}

\author{
Christina Pieri \\ School of Architecture, Design \& the Built Environment, \\ Nottingham Trent University, U.K. \\ christina.pieri2007@my.ntu.ac.uk
}

\begin{abstract}
Nicosia, the last divided European capital has been dealing with the scars of conflict since its permanent division in 1974. This division has had a detrimental impact on the historic part of the city, currently split half between the Greek Cypriot and Turkish Cypriot communities. This paper offers a critical examination of the use of façadism as an urban regeneration and heritage conservation approach, and contributes to a stronger understanding of the impact of conflict as well as division in the management of walled Nicosia's heritage. The literature review reflects on existing theory and research on the topics of heritage conservation and heritage authenticity, while a historical overview of the Cyprus conflict aims to set the ground for the analysis of the introduced data. In doing so, the paper focuses on selected areas where the use of façadism has been observed, and concludes by demonstrating that the rehabilitation of the historic city varies, with selective heritage management due to conflict and division continuing to reflect on the built environment of the city.
\end{abstract}

Keywords: Heritage management, Conflict, Façadism, Nicosia, Conservation, Authenticity

\section{Introduction}

According to Article 14 of the revised 1979 Burra Charter, conservation can be classified into different processes depending on the type and circumstances of each heritage. These classifications include retention or reintroduction, preservation and adaptation, and interpretation (ICOMOS, 2013). The aim of conservation is to look after and manage the change of a place, "so as to retain its culturally significant qualities" (ICOMOS, 2013). Bandarin et al. (2012) argue that conservation of heritage simultaneously concentrates on the past and the future by enabling an "[...] intellectual process of mediation between diverse forces, searching for an equilibrium centred on the interpretation of the value systems of a social formation." This paper examines the use of façadism as a method of conservation and urban regeneration in the south part of divided walled Nicosia, and critically discusses the impact of this approach on the authenticity of the historic built environment of the city. The case study analysis presented is grounded on the examination of relevant theory and research, accompanied by the empirical observations.

\section{Heritage}

Heritage is taken to include everything that people want to save, where "[...] it is all pervasive, and concerns everyone" (Howard, 2003).

The use and practice of heritage management has evolved into a prominent area of concern in the twenty-first century, as global issues affect the way the past is seen and used in local and global contexts. The first citations of heritage are those of 'artistic heritage' referred to by Evdipidis Fountoukidis at the 1931 Athens conference. They have since been commonly employed in the manuscripts of international organisations (ICOMOS, 1931; Vecco, 2010). 
The significance of tangible heritage was formally acknowledged with the creation of UNESCO's 1972 Convention Concerning the Protection of the World Cultural and Natural Heritage (UNESCO 1972). This guideline proved to be a turning point in the way heritage and heritage management tools were implemented in order to engage with visitors and users of heritage sites. UNESCO's 'Convention for the Safeguarding of Intangible Cultural Heritage' followed in 2003, and focuses on the intangible qualities of heritage. This document recognises the immaterial manifestations of culture as vital representations of the variety of living heritage of humanity, "[...] as well as the most important vehicle for cultural diversity" (Lenzerini, 2011).

However, in the context of Cyprus, the ongoing conflict and division between the Greek Cypriot and Turkish Cypriot communities has had a major impact on the management and protection of the island's tangible and intangible inheritance with ethnic and political differences marking the urban, social and economic structure of its capital, Nicosia.

\section{Histories of the Cypriot Conflict and the Current Division of the Island}

A prevailing matter that has historically concerned the Cypriot society relates to the topics of power, dominance and cultural conflict. More specifically, since the late sixteenth century, the constant attempts of the Greek Cypriots and Turkish Cypriots to legitimise their authority over Cyprus have resulted in continuous disagreements and ongoing inter-communal conflict [Pericleous (2009); Bose (2007)]. After the 1974 division of Cyprus into the Greek Cypriot (South) and Turkish Cypriot (North) communities, attempts by the two states to mark their supremacy and truthful belonging began to reflect on the treatment of architecture and the urban fabric; an issue also currently influencing the tangible and intangible heritage of the island . A grim consequence of this conflict is that the shared cultural heritage of Cyprus has become neglected or used as a "[...] politically motivated pawn indiscriminately played and, often sacrificed in a Machiavellian propaganda war between North and South" (Walsh, 2005). As a consequence, each community's historical narratives materialise to endorse the widespread rejection of the opposing 'other', and the continual eradication of their sorrowful memories; an outcome that influence both the tangible built environment of cities like the one of Nicosia, but also the intangible, subjective understanding of what is considered 'authentic' heritage on each side of the divide.

In line with the above, the close relationship between historical narrative and collective memory is a significant factor in the treatment of cultural heritage during, or following, the events of war or conflict. The examples discussed later in this paper exemplify this point, through the selective protection of the memories of conflict on the tangible built environment of walled Nicosia. With reference to the Greek Cypriot - Turkish Cypriot conflict, Constantinou et al. (2012) point out that the link between "[...] conflict and heritage is one loaded with assumptions about identity, otherness and the past [as well as] fraught with tension over cultural violation and communal obliteration". This phenomenon is vivid in Cyprus, where references to cultural heritage destruction occupy public discourse on either side of the divide.

\footnotetext{
${ }^{1}$ The south part of the island is known as the Republic of Cyprus (RoC) and is an internationally recognised state and part of the European Union, whereas the North is known as the Turkish Republic of Northern Cyprus (TRNC) and is only recognised by Turkey. ${ }^{2}$ Following the division of the island of Cyprus in 1974, legislation and, consequently heritage management, evolved slowly, particularly in the North. The main reason for this was the embargoes imposed by the RoC and other international organisations such as UNESCO, ICOMOS and ICCROM on the TRNC [Stylianou and Bounia (2016); Stubbs and Makaš (2011)]. More specifically, the sanctions imposed on North Cyprus by the 1954 Convention for the Protection of Cultural Property in the Event of Armed Conflict pose a significant obstacle to any heritage conservation initiatives in the North, by preventing any intervention besides "preserving cultural property in that territory" (Şevketoğlu et al., 2015). ${ }^{3}$ In the context of the Cypriot conflict and division, the concept of 'otherness' is complicated further by the existence of a tangible boundary between the Greek Cypriot and Turkish Cypriot communities. Perception of 'otherness', in this case, encompasses meanings of distance, division, duality and detachment. More specifically, through Bryant's and Papadakis' work, observations of the national GC or TC self, remain one in which "[an] ethnicised 'other' is both the cause of suffering and, [...] also on the other side of the division line” (2012).
} 


\section{Heritage management in North Cyprus After 1974}

The Constitution of the TRNC forms the basis for all legislation in the North, including provisions for the safeguarding of historical and cultural inheritance. Of particular relevance and importance to this study is Section 39 of the Constitution (i.e. Protection of historical, natural and cultural values), which outlines the role of the government in ensuring the protection of 'historical, natural and cultural heritage'. This framework has played a key role in the development of the TRNC's 1989 'Town Planning Law' and 1994 'Antiquities Law'; both of which continue to be applied and influence heritage protection today (TRNC,1985; Hoşkara, and Doratli, 2015). ${ }^{4}$

Formal interest in the protection of cultural heritage in Northern Cyprus dates back to the British Colonial period, although, some evidence of such an approach can also be seen during the Ottoman times (Hoşkara, and Doratli, 2015). Following the division of the island of Cyprus in 1974, legislation and, consequently heritage management, evolved slowly, particularly in the North. The main reason for this were the embargoes imposed by the $\mathrm{RoC}$ and other international organisations such as UNESCO, ICOMOS and ICCROM on the TRNC (Stylianou and Bounia, 2016; Stubbs and Makaš, 2011). In addition, even though amendments were made to the Antiquities Law of the TRNC in 1975 and in 1994, conservation efforts continued to be limited and less-organised than in the South due to the restricted amount of available resources. This outcome has significantly impacted the treatment of historic centres such as the one of Nicosia, with the Northern part of the city falling behind in its efforts to protect the walled city.

\section{Heritage Management in South Cyprus After 1974}

As in Northern Cyprus, the ROCs' current Antiquities Law dates back to the British Colonial period. The set of regulations introduced in 1935 "[...] was primarily intended to control archaeological excavations and protect ancient monuments of the GraecoRoman, Byzantine, Medieval and Venetian periods" (Balderstone, 2007). However, a more significant law that is relevant to urban and rural heritage in Cyprus is the 1972 'Town and Country Planning Law', which supports the protection of buildings and areas of special historical, architectural, social and other significance (Balderstone, 2007). This law was passed shortly before the island's division and has been succeeded and supported by the introduction of incentive schemes in 1985 and 1992. These incentives offer "[...] a combination of grants, low interest loans, and tax credits to assist owners of historic properties with their maintenance and restoration" (Stubbs and Makaš, 2011).

As can be observed, even though established at different times, both governments have introduced relevant legal frameworks for the protection and conservation of their cultural heritage. Despite this, the duality caused as a result of Cyprus' division significantly complicates the effective application of the

\footnotetext{
${ }^{4}$ Additional bodies that influence the management and conservation of heritage in Northern Cyprus include the Board of Antiquities and the Department of Ancient Monuments and Museums, as well as the Town Planning Department. Furthermore, the Association of the Chambers of Turkish Cypriot Engineers and Architects and the Department of Environment also play a role in the protection of heritage in the TRNC (Hoşkara and Doratli, 2015).

${ }^{5}$ More specifically, the sanctions imposed on North Cyprus by the 1954 Convention for the Protection of Cultural Property in the Event of Armed Conflict pose a significant obstacle to any heritage conservation initiatives in the North, by preventing any intervention besides "preserving cultural property in that territory" (Şevketoğlu et al., 2015).

${ }^{6}$ In 2002, the Council of Europe (CoE) called for the sanctioning of international support in the form of surveys and protection measures in Northern Cyprus in order to address the accelerated loss of heritage. However, the region's cultural heritage had already suffered as a result of its international isolation (Stylianou and Bounia 2016).

${ }^{7}$ Following the Ottoman Rule, between 1571 - 1878 AD, Cyprus was handed to Britain as part of an agreement to weaken Russian influence in the Mediterranean. However, following the Ottoman Empire's entry into the First World War on the side of Germany, Cyprus was annexed by Britain in 1914 and was subsequently declared a Crown Colony in 1925 (Mallinson 2011). Cyprus remained a British Colony until its independence in 1960, when a draft plan endorsed by the GC president and a TC vice-president was agreed under The Treaty of Establishment of the Constitution of the Republic of Cyprus (ibid.).
} 
established frameworks as issues of ownership, ethnic and political competitiveness continue to exist. Moreover, even though both frameworks are rooted in the same legislation introduced by the British in 1935, division has become the primary cause for the development of two separate legislative bases by the GC and TC governments. In addition, the embargos imposed on the TRNC by international organisations such as UNESCO, ICOMOS and ICCROM (Hoşkara, and Doratli, 2015), as well as the financial imbalances between the two governments further reinforce the inevitable development of different approaches to heritage management and protection in the North and South.

\section{Nicosia}

In line with the above, the historic core of Cyprus' capital, Nicosia has also been dealing with a multiplicity of issues associated with conflict, with the city also being divided between the Greek Cypriot and Turkish Cypriot communities. Despite the fact that the walled city has been declared a conservation area since 1989, it has experienced "[...] only a limited level of changes in practical terms as well as in attitudes towards conservation and development, [with] deterioration and decay [continuing] largely unchecked" (Doratli et al., 2004). This has resulted in the significance of its heritage neither being appreciated nor comprehended by the majority of the public (Doratli et al., 2004). In evaluating the built environment of the historic capital, many properties can be observed that illustrate its declining state. More specifically, the physical and aesthetic qualities of the city are being influenced by political, administrative, social and economic issues, which in turn, impact on the effective collaboration between the Greek Cypriot and Turkish Cypriot municipalities of Nicosia. The reason for this outcome is inevitably engrained in the on-going intercommunal conflict in Cyprus, and the continuous struggle for cultural prevalence against the 'other'.

\section{Nicosia and the Bi-communal Nicosia Master Plan}

In 1979, following the division of the city, the then mayors of Nicosia Mustafa Akinci (North) and Lellos Demetrades (South), with the support of the UN, held a historic meeting that resulted in an agreement to work together on urban issues affecting their municipalities (Hadjri et al., 2014). The initiation of the Nicosia Master Plan (NMP) included surveys, studies and plans for the walled city, with the first phase of implementation commencing in 1986 (Aga Khan Award for Architecture, 2007). The regeneration of the old town started with small improvements in the buffer zone, along with a series of local public spaces and development projects targeted at setting the groundwork and enhancing the quality of the later development phases. The NMP forms the principal strategic document that guides the investigation of design projects within the walled city of Nicosia and its surrounding vicinity (Charlesworth, 2006).

\section{Use of Façadism by the Nicosia Master Plan and its Impact on the Wider Heritage Management of Walled Nicosia}

A part of this regeneration approach has been the restoration of building façades as a means of encouraging property owners to progress with the complete refurbishment and maintenance of buildings within the walled city of Nicosia. Façadism in conservation practice has been associated with the preservation of historic façades, while demolishing or refurbishing the backs of buildings to meet contemporary demand [Henry (2013); Hernowo (2013)]. In the case of walled Nicosia, façadism also concerns the mere refurbishment of historic façades, without any regeneration undertaken to the rear sides of buildings (Nicosia Master Plan, 2005; European Commission, 2013).

According to the choice by NMP (2012) to restrict restoration to façades is due to a strategic choice made by the team to focus resources on

\footnotetext{
${ }^{8}$ These characteristics of the current qualities of walled Nicosia derive from the SWOT matrix of Cuesta et al., 1999 (in Doratli et al., 2004) In addition, the 2004 NMP Final Report (Nicosia Master Plan, 2004b), highlights the political, administrative, social and economic issues dominating Nicosia after its division by offering a justified evaluation of the up-to-date heritage management of the walled city.
}

Built-environment: Sri Lanka - Research Journal of the Sri Lanka Institute of Architects / Christina Pieri 
the attractiveness of public space. In doing so, the NMP team aimed "[to] achieve a multiplier effect and motivate the owners to complete the restoration using their own means, as well as mobilising private investment." (Siatitsa, 2012). Petridou (2005) also maintains that, the restoration of façades is aimed at upgrading and enhancing the physical environment and streetscape of neighbourhoods, while "[raising] the consciousness of inhabitants about maintaining the quality of the built environment". To achieve this, the NMP team carried out detailed surveys to safeguard the authenticity of each façade, while restoring the original elements through "compatible and reversible materials and methods" (Petridou, $2005)^{9}$. As a result, material authenticity emerges as key considerations in the restoration of historic buildings within the walls.

\section{Authenticity in Heritage Conservation}

The Venice Charter (1964) played an important role in strengthening the concept of authenticity within heritage practice. With reference to historic monuments, the preamble states that, "[...] it is our duty to hand them on in the full richness of their authenticity [...]" (ICOMOS, 1964). The characteristics of authenticity have also been expanded to embrace intangible heritage qualities such as use, function, traditions, language, spirit, and feeling (Jerome, 2008). More specifically, the 1994 Nara Document on Authenticity (ICOMOS, 1994) adopts a dynamic understanding of authenticity based on numerous aspects such as "[...] form and design, materials and substance, use and function, traditions and techniques, location and setting, spirit and feeling, and other internal and external factors" (see Article 13), which were later included in UNESCO's 'Operational Guidelines' (UNESCO, 2003). The Nara document illustrates a shift towards cultural awareness and consideration, while still making reference to the principles of the 1964 Venice Charter. More importantly, the Document recognises that authenticity in conservation practice plays a vital role in protecting the heritage of all humanity (ICOMOS, 1964).

\section{Authenticity in Divided Societies}

In divided societies, authenticity falls into a more complex category, particularly when both sides claim ownership over the same heritage. According to the 'Parliamentary Assembly Committee of Europe', a significant amount of historic buildings in their authentic form can be located within the walled city of Nicosia (Parliamentary Assembly 2002). More specifically, the Assembly refers to the tangible authenticity of the walled city, and sustains that "[...] the city shows an admirable degree of authenticity of the preserved city layout and the historical city tissue, still fully capable of salvation and reanimation in spite of its great decrepitude" (Parliamentary Assembly, 2002).

Authenticity in Cypriot heritage conservation primarily follows the doctrines of UNESCO, as well as selected ICOMOS Charters and Conventions. In addition to the fact that UNESCO's doctrines have been previously criticised for their "Eurocentric underpinnings" and for "not necessarily [bringing] the intended geo-cultural diversity and balance to the World Heritage List" (Silva, 2016), this paper also stresses the problematic nature of the current embargoes imposed by UNESCO on the TRNC, and the subsequent damage this brings on the accurate safeguarding of the authenticity of heritage on both sides of the Cypriot divide. However, the vital role of the specific organisation in setting a point of departure for heritage protection in Cyprus, and in this case Nicosia should be acknowledged, while the need for a contextspecific understanding of heritage management and authenticity is reinforced.

In the case of Nicosia, authenticity of the object is inevitably influenced by the subjective understanding of each community, along with the accompanying cultural influences. This includes the selective preservation of what is considered an authentic part of Cypriot heritage on either side of the divide, which in turn, impacts collective memory of tangible and intangible heritage as a whole. Similarly, Ashworth and Tunbridge (1994) maintain

${ }^{9}$ Provision of optional financial incentives were also made available to shop owners for the restoration of their building façades (€8,500 per shop) under the support of the EU through the UNDP/ UNOPS PFF. A total of $€ 260.00000$ was made available (Petridou, 2005).

Built-environment: Sri Lanka - Research Journal of the Sri Lanka Institute of Architects / Christina Pieri 
that heritage authenticity emerges as the outcome of a selective procedure set amongst contesting ideas. In contradiction, Lowenthal (1998) perceives heritage to be based more on faith than fact, "endowing a select group with prestige and common purpose". Relevantly, Wiles (2007) suggests that, the consequence of this development encompasses a heritage product only relevant to a specific audience, which consequently becomes detached from its real tangible artefacts. These theories present heritage authenticity as a culturallydriven, and as a selective process aiming to satisfy a particular purpose and population. Arguably, this issue becomes further amplified in the event of conflict and division, as the communities that claim ownership over shared heritage seek to unveil their individual authenticities in order to preserve their cultural beliefs. This is visible in cases such as Nicosia, where cultural competitiveness, along with desire to overlook the negative memories of conflict result in a selective promotion of cultural and architectural heritage. In such cases, understanding and treatment of 'heritage authenticity' moves away from conventional approaches to the term as it becomes contested with selective narratives; war-associated memories and politically-motivated agendas.

\section{Dionisou Street and Paphos Gate: Two Different Approaches to Façade Treatment}

A prominent example that demonstrates this approach is the one of Dionisou Street. This area primarily consists of workshops and residential buildings. Nevertheless, its proximity to the buffer zone, along with the gradual departure of long-term tenants from the area had resulted in the decay of its authentic fabric and vocational character.

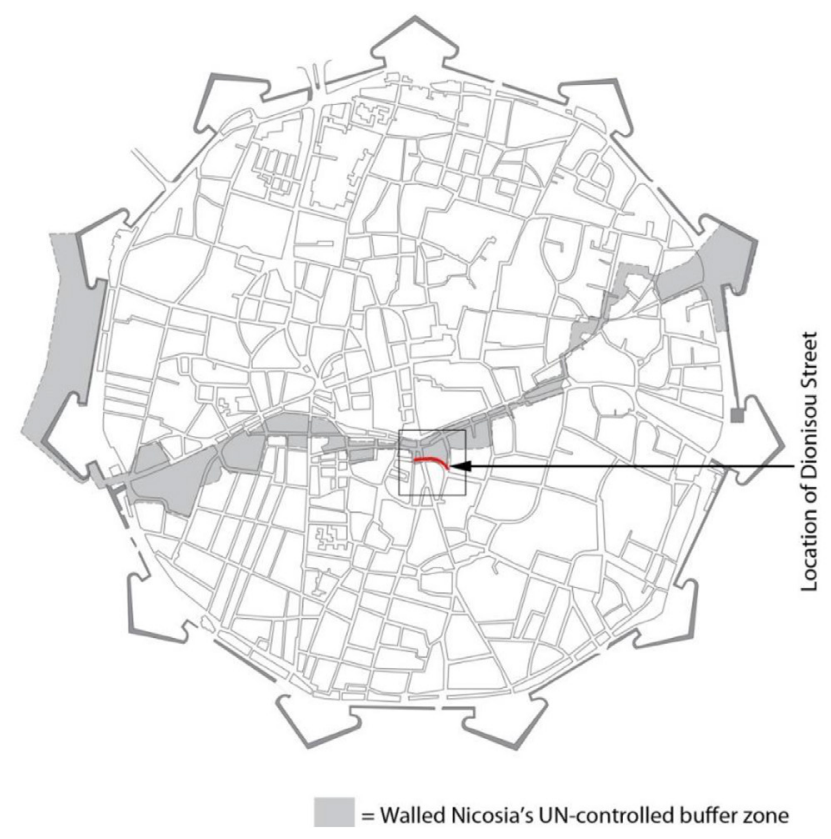

Figure 1: Map illustrating the location of Dionisou Street within the walled city of Nicosia, as well as its proximity to the UN-Controlled buffer zone Source: Author (2017) 


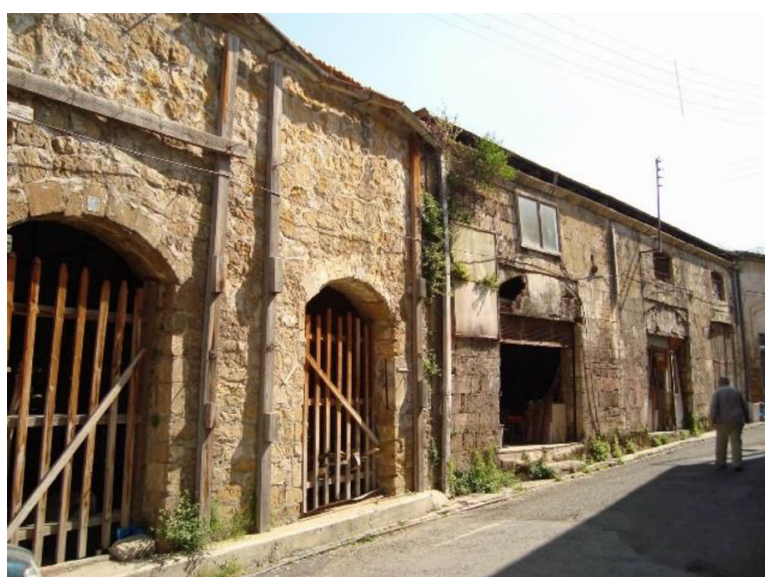

Figure 2: Dionisou Street before its rehabilitation by the NMP Source: Nicosia Master Plan office (2014a).

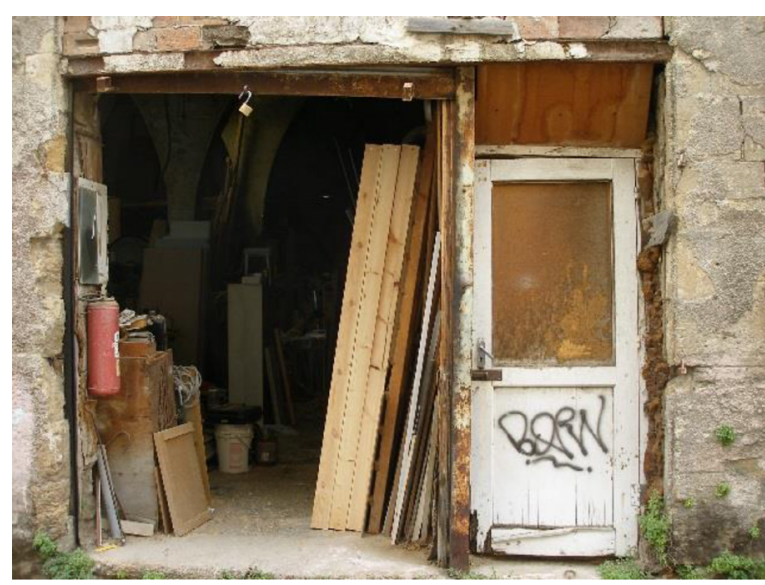

Figure 3: (bottom) Dionisou Street before its rehabilitation by the NMP Source: Nicosia Master Plan office (2014a).

Following its restoration, and despite the fact that the functionality of the area has not been completely reinstated, the NMP's goal of 'gluing' the historic city back together has visibly altered the appearance of the specific street. Nonetheless, even though the buildings have been made structurally safe before being restored, the NMP's focus was on the aesthetic upgrading of buildings, primarily through façade restorations, rather than repairing their entire structures.

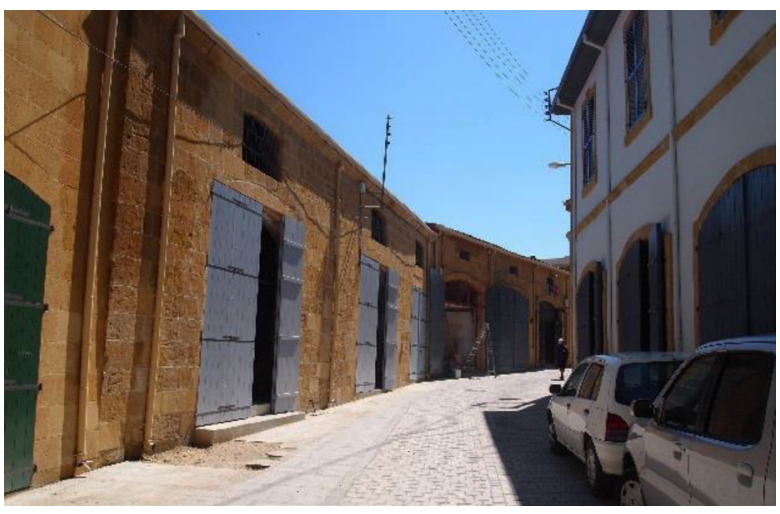

Figure 4: Restored facades at Dionisou street Source: Nicosia Master Plan Office (2014b)

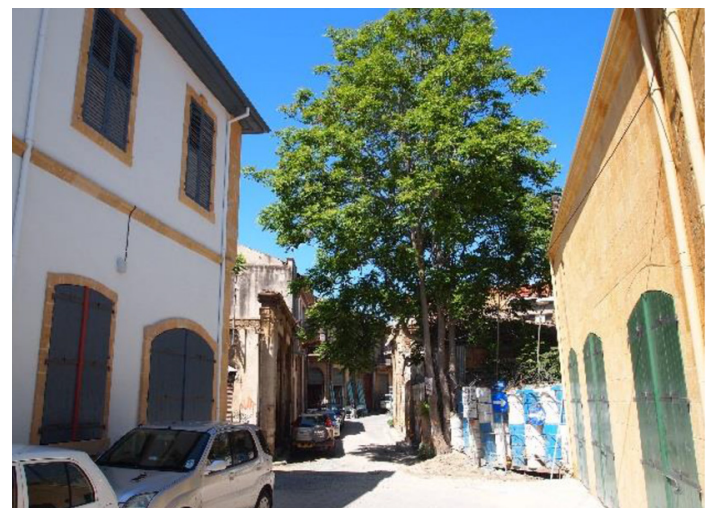

Figure 5: Restored facades at Dionisou street Source: Nicosia Master Plan Office (2014b)

The promotion of façadism and the consequent skin-deep beautification of buildings materialises as a notable conservation approach was used widely by the NMP, and was aimed at encouraging their speedy recovery as well as attracting users back to the area. Arguably, the reconstruction of damaged or declining areas next to the buffer zone could be considered as a form of healing after the conflict in 1974. Nevertheless, the skin-deep concealment of any traces of conflict and, therefore, the screening of war-associated memories suggest of a temporary solution to an ongoing problem of decline. This approach also raises concerns over the tangible and intangible authenticity of the street, with their truthful material continuity being removed through the concealment of negative, yet truthful memories; subsequently influencing public perception about the historical narrative of the restored buildings.

In addition, the field work findings have led to the observation that this method of concealing the unappealing and declining 'skin' of the buffer zone boundary is very different to the treatment of the Venetian walls surrounding Nicosia; that separate the historic and contemporary parts of the city. This observation primarily relates to the south part of Nicosia, where bullet traces have been preserved on the

${ }^{10}$ The 2004 NMP Strategy Report emphasises the significance of the buffer zone in unifying the walled city and in strengthening the links between the GC and TC Nicosia Municipalities (Nicosia Master Plan, 2004b: 20). 
external fabric of the Venetian walls. This finding raises questions associated with heritage authenticity throughout the historic core, and challenges the heritage management approach employed by the Municipality of South Nicosia. In addition, the selective treatment of heritage - and in this case, the façades of historic buildings - can be witnessed, with the existing marks of conflict influencing current conservation approaches throughout the walled city.

An example that highlights this finding is that of the Paphos Gate area, where bullet holes and other conflict-related damage on the fabric of buildings over the walls has been preserved, despite restoration initiatives on the adjacent buildings (Figure 7 - Figure 9).

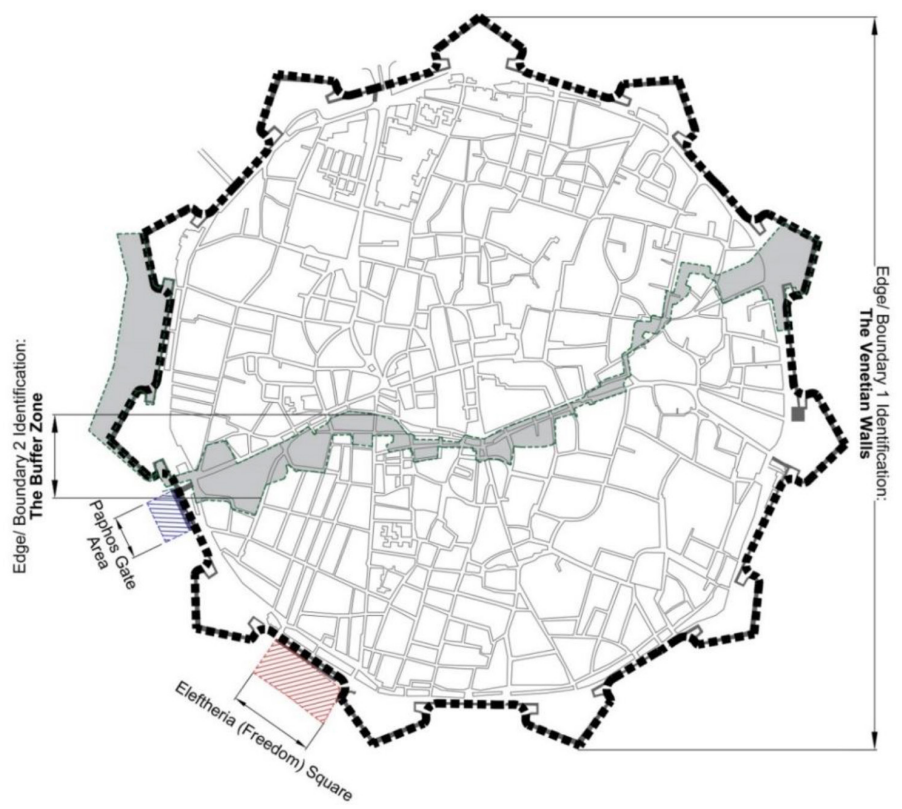

Figure 6: Edge identification diagram illustrating the location of Paphos Gate, Eleftheria Square and the different boundaries making up the physical fabric of walled Nicosia. The image shows the close proximity between the identified boundaries, despite their diverse treatment at different locations, particularly in the South part of the walled city. Source: Author (2017).

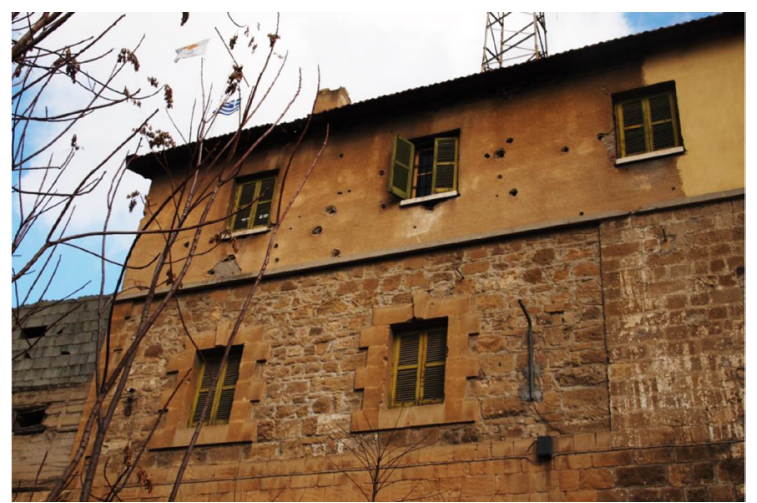

Figure 7: Governmental building (police station) next to the vehicular access and above the pedestrian access of Paphos gate. As can be observed, attempts to paint the façade (see right of picture) have been made. However, all regeneration attempts avoid the concealment of the existing bullet markings. Source: Author (2014).

\footnotetext{
${ }^{11}$ The Paphos Gate served as warehouse during the Ottoman period and as headquarters for the British Colonial police. Paphos Gate is one of the three gates built during the Venetian Period (1489-1570). The road beginning outside the gate led to the town of Paphos, hence the origins of the gate's name (Nicosia Municipality, 2017). Today the Gate is one of the main vehicular access points to the south part of the walled city and the only access (to the South) from the west part of the walls.
} 


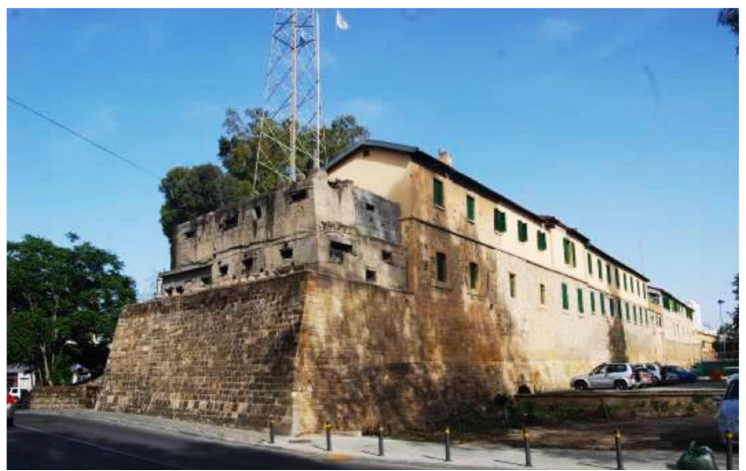

Figure 8: Vehicular access to walled Nicosia from the Paphos Gate Source: Unknown (2016)

The illustrated area of Paphos Gate is of particular tangible and intangible heritage significance to the Greek Cypriot and Turkish Cypriot communities of Cyprus, as it is one of the first and main access points to the walled city associated with commerce, surveillance and religious activities within the walls (Oswald, 2013). More specifically, Paphos Gate is one of the main entrances to the walled city that includes Venetian, Ottoman and British colonial buildings. The gate has always been a strategic position since the Ottoman and British times, and continues to function as a surveillance point under the Greek Cypriot Government, with the existence of a police station just above the pedestrian part of the gate (Figure 8). In addition, the area is associated with inter-communal riots commencing during the EOKA struggle and the Greek Cypriot - Turkish Cypriot struggle, "[which] resulted in the security forces erecting a barbed-wire fence along Paphos and Hermes Streets from the Paphos Gate to the Famagusta Gate" (Oswald, 2013). As a result, the memories associated with the Gate go beyond the tangible built environment and recall significant aspects of the Greek Cypriot - Turkish Cypriot conflict.

The contrast between the treatment of the buffer zone boundary and the Venetian walls is further highlighted through the recent renovation of building façades on Paphos Street, which is located next to the buffer zone; opposite the Paphos Gate and inside the walled city. This renovation followed the attempts of the NMP to upgrade and enhance the physical environment of the historic core (Petridou, 2005).

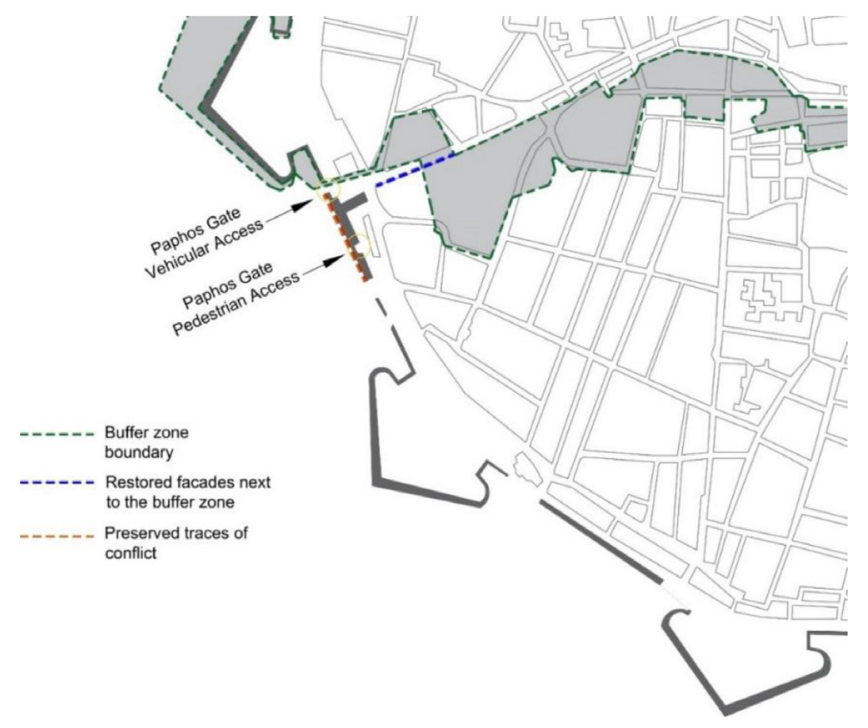

Figure 9: Map of the Paphos Gate area, illustrating the location of the newly restored façades, as well as the preserved traces of conflict Source: Author (2017). 


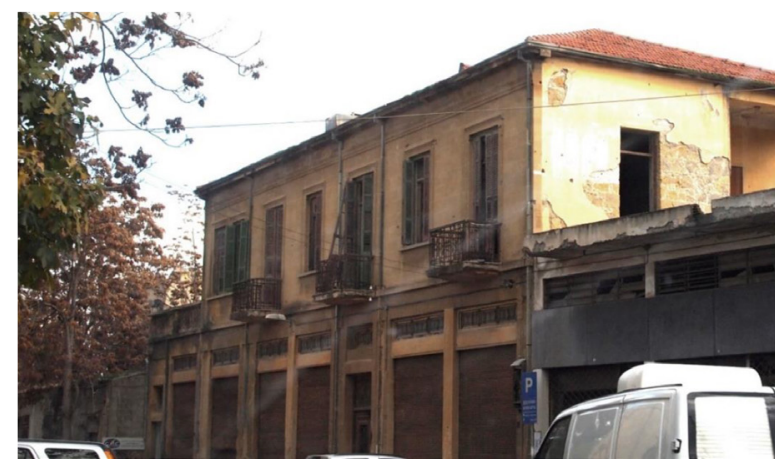

Figure 10: Façades on Paphos Street before restoration, walled Nicosia

Source: Author (2012).

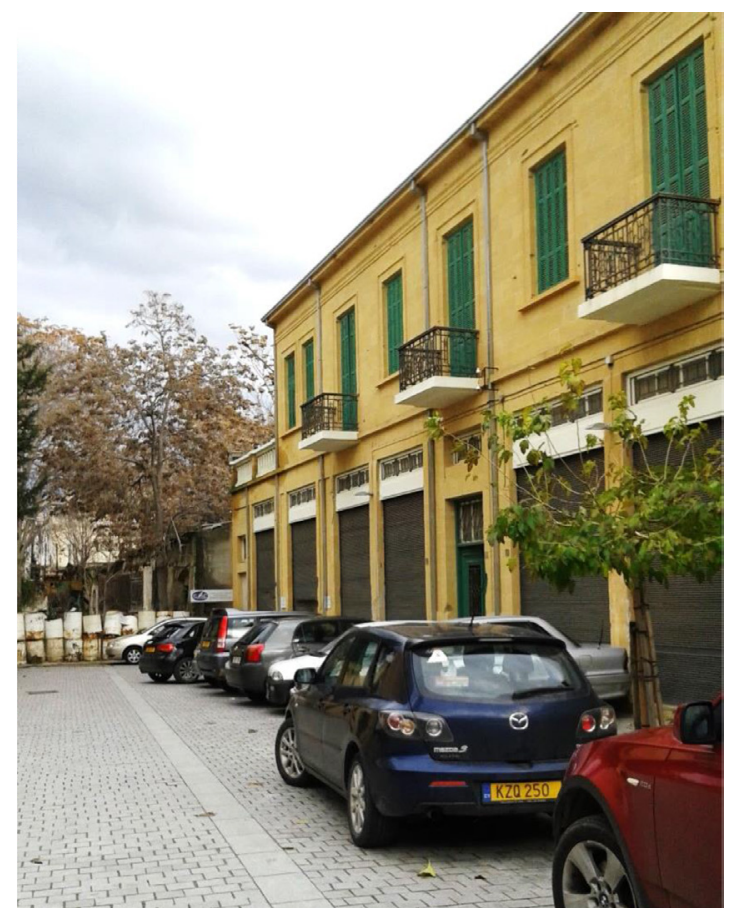

Figure 11: Recently restored building facades on Paphos Street, walled Nicosia Source: Author (2017).

Figure 10 and Figure 11 demonstrate that on Paphos Street, buildings next to the buffer zone have been restored following a similar approach to that used on Dionisou Street. In both cases, the use of façadism is visible as a key strategy for the beautification of decaying buildings and neighbourhoods. However, the example of Paphos Gate suggests of a disparity between the treatment of the buffer zone boundary, when compared to parts of the Venetian walls that have been influenced by conflict. The management of heritage in this case, differs from one area to the other, with traces of conflict being selectively preserved throughout the walled city. This phenomenon is mainly visible in the south-west part of Nicosia and closer to the buffer zone area; due to the increased number of projects undertaken by the NMP in the Greek Cypriot part of the walls.

Arguably, the fact that the memories associated with the gate differ from the memories associated with the buildings restored, further suggests of a selective use of façadism in order to accommodate a politically-driven agenda's on either side of the divide. More specifically, the fact that more historically and visually prominent buildings preserve the memories of conflict, whereas buildings of subsidiary historical and functional significance undergo - skin deep - restoration highlight a disparity on the treatment of walled Nicosia's heritage; based on the memory-value attached to individual heritage assets. 
Considering the above, it can be argued that heritage conservation is practiced differently in areas around Nicosia's Venetian walls when compared to the buildings around its buffer zone. This observation illustrates a level of heritage management inconsistency depending on the area within the historic core. This point also challenges the meanings associated with tangible and intangible heritage authenticity and the truthful historical narrative promoted by the Municipalities of Nicosia. In the case of Paphos Gate and the adjoining Venetian walls, the historical continuity of the structures has been preserved, consequently reflecting the documentary value of authenticity as promoted by early conservationists such as Ruskin and Morris . In this case, the use of façadism has not been employed as a method of healing the damaged fabric of the walls, but has intentionally been avoided to preserve the tangible and intangible memories of conflict. This finding demonstrates that issues of selective heritage management dominate Nicosia, and highlights the ongoing impact of conflict in the form of the authentic and coherent representation of the walled city.

Lastly, the examination of the walled city of Nicosia indicates that the use of façadism has been more vividly employed in the south part of the walled city (Figure 12), which has significantly contributed to the beautification of buildings and neighbourhoods. However, the fact that the practice of façadism is uniform throughout the historic core raises questions about the individual assessment of the building stock and the understanding of their unique characteristics and historical significance. The following figure illustrates the use of façadism throughout the walled city of Nicosia. As can be observed from Figure 12, a significant amount of façade restoration has been established, particularly in the south part of the walls. The image is informed by the fieldwork findings of the author as well as the information provided by the NMP, and excludes complete building restorations.
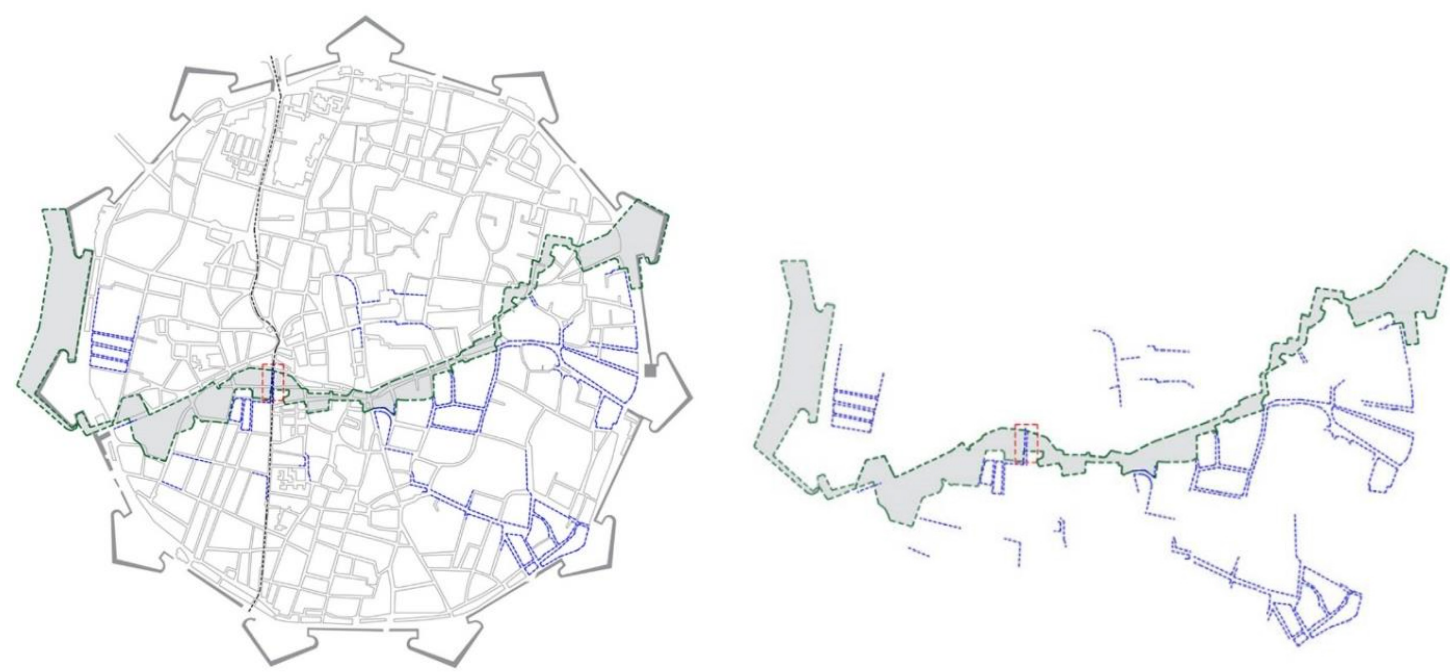

Figure 12: Figure illustrating the use of façadism throughout the walled city of Nicosia. As can be observed, funding availability for the South Nicosia Municipality - and NMP team - has encouraged the increased implementation of this approach at different locations within the walls, including areas close to the buffer zone. Source: Author (2017).

Subsequently, concerns regarding the authentic treatment of heritage relate both to the material fabric of buildings, but also to their intangible qualities that façadism may conceal. This matter contradicts the recommendations set by international charters such as Nara Document on Authenticity , as well as UNESCO's World Heritage Conventions (UNESCO 1972; UNESCO 2003). Moreover, even though the TRNC and the RoC have established a shared vision for the core city, as well as relevant legal frameworks for the protection and conservation of their cultural heritage on both sides of the divide, selective treatment of heritage through practices such as façadism need to be challenged for their long term effectiveness and holistic outcome.

${ }^{12}$ Ruskin and Morris belong to the conservation movement which reinforced the significance of a monument's material authenticity and documentary value (Jokilehto, 1999).

${ }^{13}$ For example, facades of residences that have not been affected by conflict or division have been restored analogously to facades that border the buffer zone, or have suffered damage and decay due to the 1974 conflict. In either case, the narrative attached to heritage and place is different - and so should be their treatment.

Built-environment: Sri Lanka - Research Journal of the Sri Lanka Institute of Architects / Christina Pieri 
In this vein, despite the promising outcome of the specific regeneration approach in conserving and reviving the historic core of Nicosia, the current approach to façadism poses questions regarding the authentic representation of the city after its division, and highlights the impact of conflict on heritage management decisions, as well as collective memory; particularly in the south part of the walls.

\section{Conclusions}

This paper examined the use of façadism on the walled city of Nicosia and the different applications of the specific approach throughout the historic core of the city. As the field work findings have demonstrated, façadism has been more prominently employed in areas targeted for regeneration. However, selected building skins intentionally preserve the marks of conflict as a method of safeguarding nationalist and political ideas associated with the division of the city. This approach subsequently influences tangible and intangible heritage authenticity, and raises questions about the impact of conflict as well as division on the management of the historic core. More specifically, use of this specific regeneration method has been demonstrated through the example of Paphos Gate, where nationalism and memory values appear to be more prominently protected on selected buildings.

Nonetheless, the short-term potential of façadism is recognised through this paper, as well as its promising capability to revive the historic built environment of Cyprus' capital, and encourage investment back to the walled part of the city. The considerations relating to its long-term endurance, as well as concerns connected with façadism's impact on collective memory and the authentic conservation of the walled city have been presented here; demonstrating the significance of the approach to the specific case study. Lastly, this paper highlights how the issue of selective heritage management continues to dominate the historic core of Nicosia, with conflict and division playing a primary role in the conservation of its authentic cultural inheritance.

\section{References}

Aga Khan Award for Architecture (2007). Intervention Architecture: Building for Change, The Aga Khan Award for Architecture, 10th Cycle, London: I.B.Tauris \& Co Ltd.

Ashworth, G. J. and Tunbridge, J. E. (1994) Dissonant Heritage: The Management of the Past as a Resource in Conflict, Chichester: John Wiley and Son.

Bandarin, F. and Van Oers, R. (2012) The Historic Urban Landscape: Managing Heritage in an Urban Century, New Jersey: Whiley - Blackwell.

Bose, S. (2007) Contested lands: Israel-Palestine, Kashmir, Bosnia, Cyprus, and Sri Lanka, Cambridge: Harvard University Press.

Bryant, R. and Papadakis, Y. (2012) Cyprus and the Politics of Memory: History, Community and Conflict, New York: I. B. Tauris.

Charlesworth, E. R. (2006) Architects without Frontiers: War, Reconstruction and Design Responsibility, London:Routledge.

Constantinou, C. M., Demetriou, O. and Hatay, M. (2012), 'Conflicts and Uses of Cultural Heritage in Cyprus', Journal of Balkan and Near Eastern Studies, 14(2), pp. 177-198.

Dortli, N., Hoskara, S.O. and Fasli, M. (2004), 'An Analytical Methodology for Revitalization Strategies in Historic Urban Quarters: A Case Study of the Walled City of Nicosia North Cyprus', Cities, 21(4), pp. 329-348.

European Commission. (2013), 'Evaluation of the Financial Assistance Programme for Turkish Cypriot Community', Implementing Partners: B\&S EUROPE and PROMAN, [online]. Available at: $<$ https://ec.europa.eu/info/sites/ info/files/evaluation-of-the-financialassistance-programme-for-the-turkishcypriot-community.pdf[Accessed: $1 / 06 / 2018]$.

${ }^{14}$ The 1994 Nara Document on Authenticity considers both material and immaterial qualities as vital in the preservation of heritage. These include "[...] use and function, traditions and techniques, [...] spirit and feeling, and other internal and external factors" (ICOMOS 1994).

Built-environment: Sri Lanka - Research Journal of the Sri Lanka Institute of Architects / Christina Pieri 
Gaffikin, F. and Morrissey, M. (2011) Planning in Divided Cities: Collaborative Shaping of Contested Space, New York: WileyBlackwell.

Hadjri, K., Ozersay, F. and Hadjichristos, C. (2014), 'Healing the Liminal Space: a Student Project on the Nicosia Buffer Zone', GAU Journal of Social and Applied Sciences, 6 (10). pp. 412-427.

Henry, T. J. (2013), 'Facadism as an Approach to Redevelopment and Conservation of World Heritage', Cultural Heritage and Sustainability, 5.

Hoskara, Ş.Ö. and Doratli, N. (2015), 'A Critical Evaluation of the Issue of "Conservation of the Cultural Heritage" in North Cyprus', Cyprus Review, 24(1), pp. 849-872.

Howard, P. (2003) Heritage: Management, Interpretation, Identity, Leicester: Leicester University Press.

ICOMOS (1931). The Athens Charter for the Restoration of Historic Monuments, The Athens Conference: First International Congress of Architects and Technicians of Historic Monuments, Athens, 1931, Paris: ICOMOS, [online]. Available at: $<$ http://www.icomos.org.tr/Dosyalar/ ICOMOSTR_0997330001496825715.pdf [Accessed 14/01/2019].

ICOMOS (1964). International Charter for the Conservation and Restoration of Monuments and Sites (The Venice Charter), The Venice Conference: Second International Congress of Architects and Technicians of Historic Monuments, Venice, 25-31 May 1964, Paris: ICOMOS, [online]. Available at: <https://www. icomos.org/charters/venice_e.pdf [Accessed 14/01/2019].

ICOMOS (1994). The Nara Document on Authenticity, The Nara Conference: Sixteenth International Congress of Architects and Technicians of Historic Monuments, Nara, 1-6 November 1994, Paris: ICOMOS, [online]. Available at: $<$ https://www.icomos.org/charters/nara-e. pdf [Accessed 14/01/2018].
ICOMOS (2013). The Burra Charter: The Australia ICOMOS Charter for Places of Cultural Significance, The Burra Conference, Burra, 19 August 1979 (Revised in 2013), Australia: ICOMOS» Peter Marquis-Kyle, [online]. Available at: <http://australia. icomos.org/wp-content/uploads/TheBurra-Charter-2013-Adopted-31.10.2013. pdf [Accessed 03/03/17].

Jokilehto, J. (1999) A History of Architectural Conservation, Oxford: Elzevier.

Lenzerini, F. (2011), 'Intangible Cultural Heritage: The Living Culture of Peoples', European Journal of International Law, 22(1), pp. 101-120.

Lowenthal, D. (1998) The Heritage Crusade and the Spoils of History, New York: Free Press.

Nicosia Master Plan (2004a). New Vision for the Core of Nicosia: Strategy Report. Available via: Nicosia Municipality Archive [Accessed: 01/06/2014].

Nicosia Master Plan (2004b). New Vision for the Core of Nicosia: Diagnostic Report. Available via: Nicosia Municipality Archive [Accessed: 01/06/2014].

Nicosia Master Plan Office (2014a). Dionisou Street before its rehabilitation by the NMP [photograph]. Nicosia Master Plan. Available via: Nicosia Municipality Archive [Accessed: 01/06/2014].

Nicosia Master Plan Office (2014b). Restored façades at Dionisou Street [photograph]. Nicosia Master Plan. Available via: Nicosia Municipality Archive [Accessed: 01/06/2014].

Nicosia Municipality, 2017. Paphos Gate [online]. Available at: <http://www.nicosia.org. cy/en-GB/discover/sights/paphos-gate/ [Accessed: 14/05/17]. [ill.].

Oswald, J. F. (2013) The Social and Spatial Dimensions of Ethnic Conflict: Contextualizing the Divided City of Nicosia, Cyprus, PhD Thesis, The University of Texas at Austin. 
Parliamentary Assembly (2002). Cultural Heritage of Cyprus: Information Report, Conference on The Cultural Heritage of Cyprus, Nicosia, 7 May 2002, France: Council of Europe, [online]. Available at: <http:// assembly.coe.int/nw/xml/XRef/X2H-XrefViewHTML.asp?FileID=9721\&lang=EN \#P24_221 [Accessed: 10/06/2018].

Pericleous, C. (2009) The Cyprus Referendum: A Divided Island and the Challenge of the Annan Plan, London: I.B. Tauris.

Petridou, A., 2005. Proceedings of Rehabilitation of the Urban Landscape Conference, Nicosia, 7-14 November 2005. 'Diagnosis and Intervention on Urban Facades', Nicosia: EU Partnership for the Future, [online]. Available at: <http://www.rehabimed.net/ Publicacions/Seminaris/Rehabilitacio\%20 de $1 \% 20$ pais atge $\% 20$ urba/6.2\% 20 Facades $\% 20$ and $\% 20$ storefronts.pdf [Accessed: 14/01/2019].

Sevektoğlu, M., Tuncel, R. and Şahoğlu, V. (2015), 'Protecting the Cultural Heritage of Cyprus: International Laws and Concerns', Journal of Eastern Mediterranean Archaeology and Heritage Studies, 3(2), pp. 141-148.

Siatitsa, D. (2012), 'The Walled City of Nicosia: Analytical Fiche', France: European Association for Information on Local Development (AEIDL), [online]. Available at: <https://www.aeidl.eu/ images/stories/50bestpractices/cy nicosia_analytical-fiche.pdf [Accessed: 14/01/2019].

Silva, K. D. (2016), 'Paradigm Shifts in Global Heritage Discourse', KU Scholarworks, [online]. Available at: $<$ https:// kuscholarworks.ku.edu/handle/1808/21181 [Accessed: 08/06/18]

Soja, E. (2000) Postmetropolis: Critical Studies of Cities and Regions, Oxford: Blackwell.

Stubbs, J. H. and Makas` E. G. (2011) Architectural Conservation in Europe and the Americas: National Experiences and Practice, New Jersey: John Wiley \& Sons, Inc.

Stylianou, L. T. and Bounia, A. (2016) The Political Museum: Power, Conflict, and Identity in Cyprus, London: Routledge.
TRNC, (1985). The Constitution of the Turkish Republic of Northern Cyprus, Nicosia [online]. Available at: <http:// constitutionnet.org/sites/default/files/ Cyprus\%20-\%20North\%20Constitution. pdf [Accessed: 14/01/2019].

UNESCO, 1972. Proceedings of the UNESCO General Conference, Paris. 'Convention Concerning the Protection of the World Cultural and Natural Heritage', [online]. Available at: <http://whc.unesco.org/ archive/convention-en.pdf [Accessed: 08/01/2017].

UNESCO, 2003. Proceedings of the UNESCO General Conference, Paris, 17 October 2003. 'Convention for the Safeguarding of Intangible Cultural Heritage', [online]. Available at: <http://www.unesco.org/ fileadmin/MULTIMEDIA/HQ/ERI/pdf/ MediaKit-Bali2011-EN.pdf [Accessed: 14/01/2018].

Vecco, M. (2010), 'A Definition of Cultural Heritage: From the Tangible to the Intangible', Journal of Cultural Heritage, 11(3), pp. 321-324.

Walsh, M. (2005), 'A Gothic Masterpiece in the Levant. Saint Nicholas Cathedral, Famagusta, North Cyprus', Journal of Cultural Heritage, 6(1), pp. 1-6.

\section{List of Figures}

Figure 1: Map illustrating the location of Dionisou Street within the walled city of Nicosia, as well as its proximity to the UN-Controlled buffer zone Source: Author (2017).

Figure 2: Dionisou Street before its rehabilitation by the NMP Source: Nicosia Master Plan Office (2014a).

Figure 3: Dionisou Street before its rehabilitation by the NMP Source: Nicosia Master Plan Office (2014a).

Figure 4: Restored façades at Dionisou Street Source: Nicosia Master Plan Office (2014b).

Figure 5: Restored façades at Dionisou Street Source: Nicosia Master Plan Office (2014b). 
Figure 6: Edge identification diagram illustrating the location of Paphos Gate, Eleftheria Square and the different boundaries making up the physical fabric of walled Nicosia. The image shows the close proximity between the identified boundaries, despite their diverse treatment at different locations, particularly in the South part of the walled city. Source: Author (2017).

Figure 7: Governmental building (police station) next to the vehicular access and above the pedestrian access of Paphos gate. As can be observed, attempts to paint the façade (see right of picture) have been made. However, all regeneration attempts avoid the concealment of the existing bullet markings.

Source: Author (2014).

Figure 8: Vehicular access to walled Nicosia from the Paphos Gate Source: Unknown (2016).
Figure 9: Map of the Paphos Gate area, illustrating the location of the newly restored façades, as well as the preserved traces of conflict Source: Author (2017).

Figure 10: Façades on Paphos Street before restoration, walled Nicosia Source: Author (2012).

Figure 11: Recently restored building façades on Paphos Street, walled Nicosia Source: Author (2017).

Figure 12: Figure illustrating the use of façadism throughout the walled city of Nicosia. As can be observed, funding availability for the South Nicosia Municipality - and NMP team - has encouraged the increased implementation of this approach at different locations within the walls, including areas close to the buffer zone. Source: Author (2017). 